Para Carlos Reis, pela generosa disponibilidade da escuta e pelas lições saramaguianas, impregnadas dos ecos de Eça e Garrett. 


\section{DA AGENDA AZUL AO ROMANCE DE SARAMAGO: OS MANUSCRITOS DA BIBLIOTECA NACIONAL DE LISBOA}

Nem todos os meus livros necessitam dessa investigação. Os livros que dela mais autenticamente necessitaram foram O Memorial do Convento e O Ano da Morte de Ricardo Reis. Se metes demasiada informação num romance podes tê-lo carregado de informação e não ter romance. No caso do Ano da Morte de Ricardo Reis foi bastante simples: investiguei "O Século" na Biblioteca Nacional e tomei apenas como base a leitura desse período de 36. José Saramago ${ }^{1}$

Ao participar na homenagem nacional que hoje prestamos a José Saramago, a Biblioteca Nacional, como grande instituição cultural que se preza ser, homenageia também aquele que um dia foi seu leitor. E que, sendo-o, deu uma lição de humildade e de trabalho cultural a todos os que vivem ainda a ilusão de que a criação literária é epifania vinda do nada, graças apenas ao toque fabuloso da Fortuna na fronte do escritor. Não abundam, infelizmente, tais momentos e, por isso - sabe-o bem todo o escritor que o é de corpo inteiro -, o labor e isso a que Camões chamava "honesto estudo" há-de completar um talento que, entretanto, aqui não desqualifico antes igualmente celebro. Carlos Reis $^{2}$

1 SARAMAGO, José apud BAPTISTA-BASTOS. José Saramago Aproximação a um retrato. Lisboa: Dom Quixote/Sociedade Portuguesa de Autores, 1996, p. 32.

2 REIS, Carlos. Palavras para uma homenagem nacional. Discurso proferido na homenagem nacional a José Saramago, no Centro Cultural de Belém. In:

Diálogos com José Saramago. Lisboa: Caminho, 1998, p. 167. 
Ocorre-me que esta é a primeira vez que mesclo, dois temas ou objetos pelos quais me apaixonei, desde o momento em que tomei contacto com essas duas realidades, as quais, num determinado momento da minha vida, correspondendo aos anos de 2000 e 2001, se intercruzaram e, de certa maneira, contribuíram para a construção de uma parte da minha identidade que não posso rasurar. Isto é, trato, aqui, da convergência entre o romance de José Saramago e os manuscritos da Biblioteca Nacional de Lisboa, cujos espaços, nos últimos anos, tenho percorrido com uma curiosidade sempre nova e encantada.

Ocorre-me, ainda, um outro dado que me faz apelar para uma série de experiências da minha vida que estão ligadas, à UFSM. Foi nesta casa que me graduei em Letras, em 1995, e foi, principalmente, aqui, que foi despertado em mim o gosto pela pesquisa como um processo que lança luz sobre objetos simultaneamente conhecidos e desconhecidos, mas que é, antes de tudo, um processo que exige a abertura e a sempre necessária interlocução com o outro. Não posso rasurar da minha memória que um outro elemento me liga a esta casa. Foi aqui, e em nenhum outro lugar, que descobri o romance de Saramago, cujos textos li, graças aos empréstimos da Sala de Leituras do CAL, pois os romances do autor já eram muito caros na época. Creio que o prazer da descoberta dos textos de Dom José, os quais passaram a fazer parte da minha vida e objeto constante de desejo e de encontros reiterados, tem o seu momento fundador nesse espaço da UFSM. Portanto, esta fala é, para mim, um salutar retorno às fontes, com todo aquele mágico murmúrio que elas possuem e que nos convidam a acompanhar para ver onde deságuam.

Solicitaram-me que tratasse das minhas pesquisas sobre o romance de José Saramago a partir dos manuscritos de um dos seus romances, $\mathbf{O}$ Ano da Morte de Ricardo Reis ${ }^{3}$, que se encontram depositados na Biblioteca Nacional de Lisboa, o Espólio N. 45, da Seção de Reservados dessa instituição portuguesa.

Geralmente, em uma instituição como a BN, a idéia de manuscrito e de espólio está, na maior parte das vezes, vinculada a autores que já realizaram a derradeira passagem, e que já têm por cima, pelo menos dez ou quinze anos de pesada terra. Saramago é

3 SARAMAGO, José. O Ano da morte de Ricardo Reis. $4^{\text {a }}$ ed. São Paulo: Companhia das Letras, Companhia das Letras, 1997. 
uma exceção curiosa e creio que ele acharia graça estar eu aqui a falar do seu "espólio", que, à primeira vista, consistiria no conjunto de textos e manuscritos de um autor, que já teria deixado essa vida. E, tratando-se de Saramago, com aquela ironia, que talvez me faça supor as suas últimas palavras, ele nos diria: - Pelo amor de seja lá quem for, façam isso quando eu disser a frase definitiva: Adeus, não contem mais comigo!

Mas como todos sabemos, Saramago está vivíssimo e a razão para uma parte dos seus manuscritos estar na Biblioteca Nacional se explica pelo fato de, em 1999, ano pós-Nobel, o ano saramaguiano, por excelência, o autor ter doado à Biblioteca Nacional de Lisboa, a versão datilografada do texto original e uma série de apontamentos pessoais e textos que prepararam o caminho escritural para esse romance, que o próprio autor diz ser a sua obra predileta: "No qual eu penso ter dito mais coisas!" disse Saramago certa vez. Das obras do autor foi a que exigiu a maior e mais fatigante pesquisa literária e histórica. Tinha, pois, uma relação de afeto com essas páginas originais, tendo-as colocado perto de si, em seu gabinete de trabalho.

A escritura de todos os outros textos, desde 1984, foi empreendida com os olhos postos n'O Ano da Morte de Ricardo Reis. Os originais eram uma espécie de emblema. Foi o Nobel e toda a barulheira que se seguiu, fazendo o autor peregrinar pelo mundo todo, nos dois anos seguintes, além da consciência muito apurada de "que gostava comovidamente de tudo o que Portugal havia feito dele" (Saramago), que fizeram-no começar a pensar no destino que daria aos manuscritos originais dos romances, aos apontamentos preparatórios dos seus escritos e aos textos de pesquisa documental que o acompanharam nos tempos de exercício escritural desse notável romance.

A Biblioteca Nacional de Lisboa era, sem dúvida, o melhor destino para abrigar essa parte da vida do autor, considerando a tradição da BN na organização e conservação do acervo dos grandes nomes das letras e do pensamento português. Mas havia ainda uma outra motivação, apoiada na história das leituras, que, ao longo de toda uma vida, prepararam-no e fizeram-no romancista.

Como se sabe, toda a formação de Saramago é a de um autodidata. Seu invejável acervo de leituras pessoais provém de uma disciplina pessoal férrea, que o fez, desde a juventude pobre no bairro portuário de Xabregas, lançar mão dos serviços de leitura 
oferecidos pelas bibliotecas públicas de Lisboa para construir, mesmo que ainda não pensasse em ser escritor, um conjunto de afinidades eletivas de leitura, que despontam em suas obras com a naturalidade dos intertextos e que instauram no leitor a consciência da Literatura como um jogo de revisitações constantes, de releituras, de diálogos entre textos e entre autores. Não é à toa que essa consciência a impulsionar o fazer literário aparece já, em Manual de Pintura e Caligrafia, um texto do período formativo de Saramago, ao qual foi dada pouquíssima atenção pelos estudiosos da literatura e pelos leitores. O Saramago que todos conhecemos já está presente nesse texto, que acho magnífico e do qual transcrevo um fragmento que me parece sintetizar bem o trajeto escritural de Saramago e o diálogo consciente que ele faz com a tradição literária e histórica portuguesa:

Estas coisas que escrevo, se alguma vez as li antes, estarei agora imitando-as, mas não é de propósito que o faço. Se nunca as li, estou-as inventando, e se pelo contrário li, então é porque as aprendera e tenho o direito de me servir delas como se minhas fossem e inventadas agora mesmo 4 .

A escrita romanesca torna-se, simultaneamente, ruptura e continuidade. Hoje, a um investigador atento e com algumas leituras de Literatura Portuguesa, não se torna difícil perceber e pontuar nas obras saramaguianas a emergência de algumas vozes expressivas da Literatura: Fernando Pessoa, Camões, Almeida Garrett, Eça de Queirós, Camilo Castelo Branco, Padre António Vieira, Borges, Cervantes. O prazer de poder ir localizando, aqui e ali, essas marcas ou indícios que nos proporcionam a possibilidade de delinear, ainda que imperfeitamente, uma história pessoal de leitura do autor, remete-nos aos espaços concretos, nos quais essas leituras foram feitas ou impulsionadas.

Em se tratando de Saramago, na construção do seu conjunto de leituras, a Biblioteca Nacional ocupa um lugar fundamental, pois foi na sala de leitura geral que, durante anos,

4 Idem. Manual de pintura e caligrafia. São Paulo: Companhia das Letras, 1998, p. 91-92. 
noite após noite, o autor se dirigia para ler livros que não podia comprar e os jornais portugueses do dia.

Creio que, ao doar os manuscritos de $O$ Ano da Morte de Ricardo Reis, o romancista expressava a sua gratidão pela $B N$, no que toca a sua própria formação de leitor, inseparável da condição de escritor reconhecido e aclamado, que depois viria a ser. Mas há mais. A doação expressa o reconhecimento do autor, não só pelas informações preciosas oriundas dos arquivos da BN, e que depois seriam reinventadas pelo romance, mas insiste no papel dessa instituição como uma espécie de guardiã da memória escritural portuguesa que, de uma dissertação de mestrado, passando pelos lançamentos anuais das editoras portuguesas, até os textos literários da Idade Média galego-portuguesa, procura preservar e manter esses textos para "todos os portugueses".

Com a doação, o romancista reconhecia que o principal objetivo da BN era o de não só pôr ao serviço da vida intelectual e cientifica de Portugal toda a memória cultural que constitui o seu acervo, mas também projetar essa memória cultural para a sociedade portuguesa e para o exterior, desempenhando, assim, um importante papel de difusão do conhecimento elaborado pelos portugueses, mas não só por esses, por todos aqueles que se expressam em Língua Portuguesa. A BN é um caso especial de reunião do conhecimento acerca do mundo lusófono. É encantador poder ver, em seus corredores, salas de leitura e arquivos a nossa Língua ser desdobrada por portugueses, africanos, brasileiros, indianos, chineses e, mais recentemente, por timorenses. A língua materna estabelece laços de fraternidade dos quais não se pode fugir. Ela instaura indubitavelmente a consciência do "Nós".

Em um dos parágrafos anteriores, eu falava que a obra de Saramago é para mim um objeto de desejo e de reencontro constante. Ao longo desses anos, tive a oportunidade de ler vários escritores portugueses e a atividade do ensino superior colocou diante de mim uma série de textos poéticos, narrativos e dramáticos, cujos níveis de envolvimento foram muito diferenciados. A leitura tem inevitavelmente esses dois pólos: a repulsa ou o envolvimento prazeroso em relação ao universo descortinado pelo texto. Julio Cortázar escreveu, certa vez, acerca do conto e creio poder aplicar ao romance: "Que, às vezes, um bom texto nos pega por nocaute"5.

5 CORTÁZAR, Julio. Valise de cronópio. 2. ed. São Paulo: Perspectiva, 1993. 
Acabamos nos agarrando nas cordas, completamente rendidos e esmagados. A narrativa de Saramago produz isso comigo. Há algo, nessa narrativa, com que me identifico. Não falo de um estranhamento causado pelo bem conseguido manejo de alguns recursos escriturais ou da ironia corrosiva e aliciadora que essas obras instauram. Nessas obras, há algo que me comove profundamente, pois creio que encontro nelas uma espécie de movimento, de entranhada melancolia e risonha ironia que também são muito minhas.

Penso que poderia sintetizar a minha relação com a obra de Saramago da seguinte maneira: no final dessas leituras sempre saio muito abalado e perplexo. Apesar do pessimismo e da crítica feroz e corrosiva que emanam desses textos, vejo, neles, a emergência de uma espécie de esperança em relação ao gênero humano. É como se 0 romance nos lembrasse a necessidade de continuar obstinadamente resistindo e vivendo, apesar de tudo. Essa necessidade aparece emblematicamente na voz de Maria Sara, personagem do romance História do Cerco de Lisboa, que, ao acompanhar Raimundo Silva acabar a escrita da sua História do Cerco de Lisboa, aquela que tomou ao pé da letra a infração cometida contra um livro de História oficial e que surge como uma visão alternativa dos fatos em relação ao discurso historiográfico conhecido, comenta o que segue:

São três horas da madrugada. Raimundo pousa a esferográfica, levanta-se devagar. Entra no quarto, que uma luz fraca apenas ilumina, e despe-se cautelosamente, evitando fazer ruído, mas desejando no fundo que Maria Sara acorde, para nada, só para poder dizer-Ihe que a História chegou ao fim, e ela, que afinal não dormia, pergunta-lhe, Acabaste, e ele respondeu, Sim acabei, Queres dizer-me como termina, Com a morte do almuadem, E Mogueime e Ouroana, que foi que lhes aconteceu, Na minha idéia, Ouroana vai voltar para a Galiza, e Mogueime irá com ela, e antes de partirem acharão em Lisboa um cão escondido, que os acompanhará na viagem, Por que pensas que 
eles devem ir embora, Não sei, pela lógica deveriam ficar, Deixa-lá ficamos nós 6 .

"Deixa-lá, ficamos nós", diz Maria Sara ao exprimir essa intrigante continuidade que a obra promove em relação ao leitor. $O$ mistério da escrita literária está nisso também. Sabe-se lá quem irá continuá-la, quando e como. Como já devem ter percebido, estou a falar de mim. Ou melhor, tento falar da presença da obra de Saramago em mim. Preciso disso para falar do meu trajeto de pesquisa, que, no meu entender, não posso fazer sem essas balizas. Para falar a verdade, não me julgo nem me acho ainda um pesquisador, no sentido pleno do termo. Entendo a pesquisa como produção de conhecimento, que possa, de alguma maneira, renovar algum aspecto da cultura humana, como um processo que lança luz sobre algo que, até então, havia ficado à margem de um olhar perscrutador. Seria muita pretensão minha dizer que renovo alguma coisa em termos de estudos saramaguianos, que é um dos meus âmbitos de pesquisa e que creio, enquanto eu existir, vai continuar a ser um caminho a ser percorrido de forma incessante.

Acho que ainda não produzo conhecimento sobre Saramago, mas reúno daqui e dali algumas idéias. Seja como for, não perco de vista uma das metas que já havia estabelecido quando era bolsista do PIBIC, aqui nesta casa. Qualquer que seja o processo de produção do conhecimento no qual venha a me envolver, ele deve ser uma solicitação nascida de uma aspiração muito íntima.

Preparando este texto, lembrei-me de um escrito de Roland Barthes, que descobri, quando era bolsista, e que sempre gosto de reler, Jovens Pesquisadores, publicado na França, em 1972, no livro Communications, e, no Brasil, na década de oitenta, no livro O Rumor da Língua. Destaco um pequeno fragmento, que parece servir bem para todos nós, jovens pesquisadores, que estamos começando a prática da pesquisa em Letras:

6 SARAMAGO, José. História do cerco de Lisboa. $4^{\text {a }}$ ed. São Paulo: Companhia das Letras, 1996, p. 348. 
O trabalho de pesquisa deve ser assumido no desejo. Se essa assunção não se dá, o trabalho é moroso, funcional, alienado, movido apenas pela necessidade de prestar um exame, de obter um diploma, de garantir uma promoção na carreira. Para que o desejo se insinue no meu trabalho, é preciso que esse trabalho me seja pedido não por uma coletividade que pretende garantir para si o meu labor (a minha pena) e contabilizar a rentabilidade do investimento que faz em mim, mas por uma assembléia viva de leitores em que se faz ouvir a voz do Outro e não o controle da lei. Ora, em nossa sociedade, em nossas instituições, o que se pede ao estudante, ao jovem pesquisador, ao trabalhador intelectual, nunca é o seu desejo. Quisemos aqui que o trabalho de pesquisa fosse, desde 0 princípio, objeto de uma solicitação forte, formulada fora da instituição e que só podia ser uma solicitação de escritura. Bem entendido, o que figura neste número é apenas um pedacinho da utopia, pois sabemos que a sociedade não está pronta para conceder com largueza, institucionalmente, ao estudante, e singularmente ao estudante de "letras", essa felicidade: que se tenha necessidade dele; não de sua competência ou de sua função futuras, mas de sua paixão presente"7.

Barthes insiste na dimensão do desejo a impulsionar o processo de investigação literária e a sua conseqüente escritura. Ao falar da pesquisa na nossa área, o pensador francês destaca a necessidade de escrever, de dizer-se e colocar-se no branco da página, mesmo que isso signifique ser feito de forma imperfeita e limitada. Nesse processo de escritura, ele fala da necessidade de uma paixão que deve estar sempre presente. É nesse ponto que

7 BARTHES, Roland. Jovens pesquisadores. In: O rumor da língua. São

Paulo: Brasiliense, 1988, p. 97. 
gostaria de deter-me um pouco, pois acho que, às vezes, o peso institucional é muito árduo para se carregar e acabamos enveredando por caminhos de investigação, que, nem sempre correspondem aos nossos desejos mais íntimos. Como todos sabemos bem, ao ingressarmos num programa de mestrado ou de doutorado, imediatamente tomamos contacto com um ramalhete de linhas de pesquisa, às quais nossos possíveis orientadores estão vinculados e sob a égide das quais eles apóiam a suas respectivas produções intelectuais e inclusive a sua ação como orientadores. $\mathrm{Na}$ linguagem das instituições que administram a pesquisa nesse país, há a necessidade de uma adequação estrita, pois estamos sendo constantemente vigiados, cobrados e avaliados. E sem essa adequação não há reconhecimento pelos órgãos responsáveis, tampouco algum pouco de dinheiro, que, quando chega à universidade, sempre chega em boa hora. Pode parecer que não concordo com tais adequações e avaliações. Muito pelo contrário. Devemos parar de pensar que os professores universitários, sobretudo aqueles que trabalham em Pós-graduação, sabem tudo ou que podem orientar sobre tudo. É necessário um recorte seletivo, senão corremos o risco de nos portar como bombas de fragmentação, que, de acordo com modismos, centenários de nascimento e morte de autores, prêmios Nobel e Congressos da hora acabamos nos envolvendo com áreas e objetos de estudo que nem sempre correspondem aos nossos desejos mais íntimos de investigação. Volto a insistir na idéia do desejo descortinado pela citação de Barthes. Isto é, é necessária a busca do saber, a construção do conhecimento, mas também, o sabor e, no nosso caso, tratando-se de Literatura, o sabor e o prazer que só um bom texto literário pode nos proporcionar.

Insisto com essa idéia da necessidade da paixão sempre presente para falar da minha investigação sobre Saramago, que já produziu uma dissertação de mestrado, uma tese de doutorado, um livro, dois outros que estão em preparação e alguns artigos de circunstância. Eu não teria feito esse pouco que fiz, até agora, se não tivesse sido fiel àquele desejo fundador, despertado aqui na UFSM, de estudar Saramago pela vida afora.

Esse desejo me conduziu num primeiro momento a um romance particular, a História do Cerco de Lisboa (1989). Sempre considerei essa obra um texto difícil para uma análise teóricocrítica, considerando, sobretudo, os deslocamentos temporais 
operacionalizados pelo romance, que conjuga a trajetória de dois conjuntos de duplos: Raimundo Silva e Maria Sara que, no século $X X$, escrevem, à medida que um amor outonal nasce entre eles, uma História do Cerco de Lisboa, na qual os cruzados estrangeiros não ajudarão a conquistar a moura Lisboa e na qual emerge a história do amor de Mogueime e Ouroana, duplos de Maria Sara e Raimundo Silva. No final da releitura dessa obra, quando decididamente a considerei o meu objeto de estudo para a elaboração da dissertação de mestrado, fui tomado por uma comoção/percepção idêntica à que ocorrera, quando li o Grande Sertão Veredas de Guimarães Rosa. E lembro, ainda hoje, o pensamento que iluminou a leitura realizada: "Quando voltarei a ler um romance tão bom?" Diante dos meus olhos de pesquisador iniciante, eu definia, em termos de desejo e paixão, o objeto que eu queria "cercar" sob a perspectiva de uma investigação sobre a tênue fronteira entre a Literatura e a História.

Essa narrativa de Saramago oferecia-me não só a adequação à proposta do trabalho sobre a interlocução entre os discursos da Literatura e da História, portanto um trabalho de Literatura Comparada, mas sobretudo aquela perspectiva da paixão pela pesquisa, que eu tinha muito claro que deveria estar inevitavelmente presente no trabalho que viesse a redigir.

O diálogo entre a Literatura e a História sempre me fascinou e, juntamente com os clássicos, minhas afinidades de leitura sempre recaíram sobre romances de temática histórica ou sobre trabalhos escritos por historiadores. Textos nos quais o "manto diáfano da fantasia" atribui à Literatura uma dimensão documental, no que tange à propriedade íntima do discurso literário de proporcionar ao leitor conhecimento sobre a experiência humana no e com o tempo, como escreve Ricouer ${ }^{8}$. Sublinha-se, assim, a consciência de que o discurso sobre o passado, seja ele o Literário ou o histórico, é uma representação, sem qualquer pretensão de recuperar o fato histórico pleno ou o real como efetivamente fora.

No meu caso, não era só isso o que interessava, em termos de redação de uma dissertação de mestrado, que incidia sobre um dos romances menos estudados do Saramago, e que eu já vislumbrava como uma espécie de divisor de águas dentro dessa

8 Cf. RICOEUR, Paul. Poética da narrativa: História, ficção, tempo.

In:_. Tempo e narrativa. Tomo III. Campinas: Papirus, 1997, p. 173-273. 
obra. Em outras palavras, subliminarmente, eu me perguntava de onde provinha essa minha fascinação pela História e, principalmente, por uma História que, para mim, chegava através do romance.

Estou convencido de que esse gosto emerge paradoxalmente de uma espécie de vazio, de anseio por alguém que contasse ou reabilitasse, pelo ato de contar, uma faculdade suspensa, adiada, adormecida, mas nunca perdida irremediavelmente. E a História do Cerco de Lisboa de Saramago, com seu acento na voz proverbial do contador de histórias, parecia suprir esse anseio. Essa voz torna-se magicamente proverbial e faz-nos reconhecer uma entoação que lembra a atitude de silêncio, de encantamento e absorção total com que ouvíamos as histórias que alguém nos contava na infância.

E Saramago explorou muito bem esse debatimento íntimo do romance na busca de uma escrita promotora da arte de contar, sem cair, contudo, numa representação passiva e servil da História. Saramago procurou alcançar o gosto aliciador próprio do contar tradicional com uma narratividade nova:

Todo o romance é isso, desespero, intento frustrado de que o passado não seja coisa definitivamente perdida. Só não se acabou ainda de averiguar se é o romance que impede o homem de esquecer-se, ou se é a impossibilidade do esquecimento que o leva a escrever romances ${ }^{9}$.

Nesse romance, a transfiguração da História não impulsiona o leitor a detectar, aqui e ali, elementos ou dados históricos facilmente identificáveis, reduzindo o universo romanesco ao registro de um compromisso com uma verdade compendiada e respaldada oficialmente. O romance não se limita a ser uma recriação temporal da Idade Média portuguesa. A História do Cerco de Lisboa nos faz vagar pelos meandros e sendeiros da História. Para Saramago, o esforço de transfiguração do passado será sempre regido e condicionado pelo imaginário. Tratando-se de um tempo remoto como a Idade Média, sobre os traços tênues e

9 SARAMAGO, José. História do Cerco de Lisboa. Op. cit., p. 56. 
descontínuos do passado só se pode construir uma armadura que, no entanto, é muito frágil, pois entre os poucos esteios permanece aberta a incerteza. $\mathrm{Na}$ tentativa ficcional que o romancista português levou a termo, a Idade Média precisou ser sonhada. Este delírio lúcido celebra o encontro com o passado, recriando-o e preenchendo os vazios existentes através do sonho, da fantasia e da imaginação10.

A narrativa do autor não se restringe ao movimento simples e unívoco de refletir especularmente a história medieval lusitana, pois a narração volta-se sobre si mesma, sabendo-se sonho e medindo-se enquanto tal, afundando nessa treva silenciosa, no abismo em que o espírito da narração se perde a si mesmo, auscultando a pulsação do seu próprio universo interior, dos seus mecanismos de representação e escrita, de transfiguração e, se for o caso, de infração de uma história da qual só restaram murmúrios.

Acerca desses murmúrios deixados pelos seres humanos, ao longo do tempo, é Georges Duby, um dos mestres da História Nova, que lembra que o processo de escrita sobre o passado se assemelha ao deslocamento no interior de um arquipélago de vestígios e murmúrios. A invenção, a imaginação e a criação são insinuadas no interior desse arquipélago. Neste, há grandes blocos, bem presentes, que se impõem; outros são mais tênues. Entre estes se divaga à vontade; e há grandes espaços onde podemos imaginariamente nos espraiar com muito prazer ${ }^{11}$.

Foi essa possibilidade de poder me espraiar com prazer que me levou a sondar como poderia promover a dita interlocução entre a Literatura e a História em História do Cerco de Lisboa. Como o trabalho estava inserido na área da Literatura Comparada, era evidente que uma perspectiva contrastiva/comparativa deveria orientar a elaboração do estudo. Empreendi um levantamento criterioso e minucioso de todos os fatos históricos reinventados pelo romance, no que tange à conquista de Lisboa em 1147, período em que a cidade era um dos baluartes do Islã em terras ibéricas. Esse processo de comparação esbarrou em um ponto, isto é, a limitação de matérias teórico-críticas, existentes no Brasil acerca da Idade

10 ROANI, Gerson Luiz. No limiar do texto: Literatura e história em José Saramago. São Paulo: Annablume, 2002, p. 26.

11 DUBY, Georges \& LARDREAU, Guy. Diálogos sobre a Nova História. Lisboa: Dom Quixote, 1989, p. 38-39. 
Média ibérica. Claro está que existem excelentes textos que versam sobre as formas assumidas pela Literatura na Idade Média, mas são inexistentes textos ou registros historiográficos oriundos desse período e portadores de uma carga testemunhal evidente em relação ao acontecimento histórico que está sendo cercado.

No caso do romance de Saramago, a Idade Média portuguesa é metonimicamente transfigurada por um conjunto específico de eventos que caracterizam a conquista de Lisboa pelos portugueses e cruzados estrangeiros, em 1147. Na tessitura dessa narrativa são evidentes as menções a textos medievais como A Crônica dos Cinco Reis, A Crônica da Conquista de Santarém, A Carta do Cruzado Osberno, A carta de Arnulfo, A Carta de Duodechino e a Crônica da Fundação do Mosteiro de São Vicente de Fora e a História da Vida e Obra de Santo António de Frei Bernardo de Britto.

Como ter acesso, no Brasil, a textos historiográficos medievais como esses? Nas próprias instituições portuguesas eles são raros e de difícil acesso. O ideal seria utilizar essas obras para realizar o dito contraste entre Romance e História no âmbito da produção saramaguiana em questão. Cerquei-me de vários livros sobre a Idade Média portuguesa, mas nenhum deles oferecia-me a possibilidade da comparação tão desejada. Nesses momentos, os sendeiros da Literatura acabam nos proporcionando algum tipo de iluminação.

Acabei me detendo num trecho da História do Cerco de Lisboa, na qual Saramago faz uma nítida referência intertextual à obra historiográfica de Alexandre Herculano:

Raimundo Silva olhou o papel, Ouvide, então, agarrou na esferográfica para prosseguir 0 relato, mas percebeu que tinha o cérebro vazio, outra vez uma página branca, ou negra de palavras sobrepostas, entrecruzadas, indecifráveis. Depois do que declarara D. Afonso Henriques, não tinha mais que, por palavras suas, contar o milagre de Ourique, introduzindoIhe, claro está, a esperada porção de cepticismo 
moderno, aliás autorizada pelo grande Herculano, $(\ldots)^{12}$.

E, como numa espécie de decalque, encontrei, passagem por passagem, na História de Portugal de Alexandre Herculano ${ }^{13}$, a mesma seqüência de fatos relativos ao cerco de Lisboa, recriada por Saramago, no seu romance. O ficcionista se debruça e reinventa os mesmos episódios privilegiados por Herculano e existem passagens que são literais. O exercício ficcional de Saramago defende que, em Literatura, nada é superado e que, ao dialogar com a História de Portugal de Herculano, o romancista contemporâneo colocava-se, do ponto de vista de escrita da História, algumas questões que o próprio Herculano havia posto em seus romances e textos historiográficos do Oitocentos português.

Isto é, a História de Portugal devia ser tratada sem louvações patrióticas. Herculano é, no terreno da Historiografia portuguesa, a primeira voz que elege Portugal como um objeto de uma interpretação crítica severa. Seus romances são alimentados pela preocupação de estabelecer, na Idade Média, as origens da nacionalidade portuguesa, conferindo, às vezes, um peso discursivo muito maior à História do que propriamente à Literatura. E, no âmbito da Historiografia, ele empenhou-se em criar as bases para uma perspectiva de escrita do acontecimento histórico que fosse interventiva e problematizadora dessa "entidade" chamada Portugal. O autor da História de Portugal adotava uma postura que vislumbra a História e o romance como instrumentos discursivos eficazes de transformação de estruturas sociais e culturais.

É Eduardo Lourenço que, em O labirinto da saudade ${ }^{14}$, fala de Herculano e, também, de Almeida Garrett, como os dois nomes nos quais a integridade humana aliou-se à primeira grande tentativa de "interpretar" Portugal através da ficção literária, sem a característica grandiloqüência e provincianice incurável, adotadas pela conservadora intelectualidade lusitana. Esse processo de

12 SARAMAGO, José. História do Cerco de Lisboa. Op. cit., p. 145.

13 HERCULANO, Alexandre. História de Portugal: desde o começo da monarquia até o fim do reinado de Afonso III. Vol I. Lisboa: Bertrand, 1980.

14 LOURENÇO, Eduardo. O labirinto da saudade. Psicanálise mítica do destino português. Lisboa: Gradiva, 2000, p. 80- 118. 
interpretação será assumido e intensificado, algum tempo depois, nas engenhosas narrativas de um Eça de Queirós. Apelando para a História de Portugal de Herculano, eu solucionava o meu problema de comparação instaurado pelo romance.

Seja como for, dediquei, na minha dissertação de mestrado, pelo menos, três longos capítulos para explorar essa relação intertextual entre o romance saramaguiano e a obra de Herculano. Como se sabe, uma das artimanhas da criação ficcional é o mascaramento das fontes. Lembrando Benjamin, em um dos textos de Rua de Mão Única, "O coelho da Páscoa descoberto ou Pequeno Guia dos esconderijos", a escrita literária simultaneamente esconde e mostra os seus recursos de codificação escritural. Ouçamos o Benjamin, pois creio que posso aplicar o que diz o filósofo ao processo de investigação do texto saramaguiano, que descrevo aqui: "Esconder significa: deixar rastos. Porém, invisíveis. É a arte da prestidigitação. Quanto mais aéreo um esconderijo, tanto mais engenhoso. Quanto mais livremente estiver exposto a todos os olhares, tanto melhor"15.

Esse procedimento de esconder e mostrar, eu voltei a encontrar, no momento em que elaborava uma tese de doutoramento sobre $O$ Ano da Morte de Ricardo Reis, romance publicado em 198416. Após o processo de elaboração da dissertação de mestrado, eu tinha a clareza e a dose necessária de entusiasmo para continuar trabalhando com o Saramago. De uma ponta à outra, percorri a obra de Saramago, realizando um estudo prévio da fortuna crítica dedicada a todos os romances do autor.

Isso originou uma pesquisa bibliográfica que, naquele período, localizou, em bibliotecas portuguesas, brasileiras, italianas e norte-americanas, cerca de 350 textos críticos sobre a produção artística de Saramago. Espantosamente, a recepção de Saramago no Brasil havia originado muitas teses e dissertações em universidades brasileiras. Mas um olhar organizador desses

15 BENJAMIN, Walter. O coelho da Páscoa descoberto ou Pequeno guia dos esconderijos. In: Rua de mão única. Obras escolhidas II. $4^{\mathrm{a}}$ ed. São Paulo: Brasiliense, 1994, p. $237-239$.

16 Cf. ROANI, Gerson Luiz. A história comanda o espetáculo do mundo: Ficção, História e Intertexto em O Ano da Morte de Ricardo Reis de José Saramago. Porto Alegre: PPGLETRAS/ UFRGS, 2002, 377 p. (Tese de Doutorado em Literatura Comparada). 
materiais tão variados constatou que a maior parte desses estudos era dedicada a três romances de Saramago, A Jangada de Pedra, O Evangelho Segundo Jesus Cristo e Memorial do Convento.

O mais curioso era que, em Portugal, apesar da existência de inúmeros textos circunstanciais sobre todos os romances do autor, eram poucas as investigações acadêmicas de fôlego sobre essas narrativas. Na época uma pesquisa na PORBASE acabou detectando pouca coisa. Creio que esse quadro não se modificou muito até agora. Nesse panorama, há que destacar a produção crítica de investigadores portugueses como Maria Alzira Seixo, Carlos Reis, Manuel Gusmão, Miguel Real, Ana Paula Arnaut e Maria de Fátima Marinho, que, ao estudarem as coordenadas escriturais do novo romance português, surgido após o vermelho dos cravos de abril, tem conferido a Saramago o lugar engenhoso e renovador que lhe cabe, por direito, dentro da Literatura Portuguesa contemporânea.

Eliminando esses romances anteriormente apontados, ficavam à mercê de um olhar interrogativo quase todos os outros textos: a História do Cerco de Lisboa, o Levantado do Chão, as peças de teatro, os poemas, as crônicas, O Ano da Morte de Ricardo Reis e, naquela altura, produções novíssimas, tais como Todos os Nomes e O ensaio sobre a cegueira. Surpreendi-me com a complexidade de fabulação narrativa de $O$ Ano da Morte de Ricardo Reis e o escolhi como objeto de estudo para o doutoramento.

Eu permanecia fiel ao meu desejo de continuar trabalhando com a interlocução entre a Literatura e História em José Saramago, mas havia algo que me assustava. Em outras palavras, a revisitação promovida pelo romance da vida e da obra de Fernando Pessoa. Esse processo escritural expressa narrativamente a continuidade de um jogo com a heteronímia pessoana, que a morte do poeta, em 1935, não impôs ao romancista contemporâneo.

A obra poética de Pessoa é singular, clássica e invulgar. Qualquer revisitação feita por músicos, romancistas, artista plásticos ou investigadores da Literatura, deve reconhecer imediatamente que está lidando com um "mito", com uma das figuras mais expressivas da Literatura Portuguesa de todos os tempos e, sem dúvida, a mais importante figura literária do século XX português. 
Philippe Sellier afirma que o mito literário é um elemento, no qual uma coletividade se reconhece 17 . O romance de Saramago é uma das muitas revisitações feitas da obra e da vida pessoana, ao longo dos últimos tempos. Nesse sentido, não pode ser esquecido um romance como o do italiano Antonio Tabuchi, inúmeros poemas dedicados ao poeta e ao seu universo poético por autores de várias línguas, as adaptações dos seus textos para o teatro e as revisitações musicais da sua obra, feitas por músicos brasileiros e portugueses.

Saramago escreve esse romance, em 1984, um ano antes do translado dos restos mortais do poeta para o Mosteiro dos Jerônimos, espécie de panteão, onde estão enterrados alguns vultos importantes da História portuguesa. Não pode ser esquecido que, em 1984, comemoravam-se os dez anos da Revolução dos Cravos, a qual havia posto fim a uma ditadura de 50 anos. Dez anos é o tempo suficiente para as pessoas esquecerem. E, em Portugal, passou a ocorrer, em certos setores mais conservadores, uma espécie de negação da repressão promovida pelo salazarismo: Nunca existiu ditadura! O fascismo nunca existiu entre nós portugueses! O salazarismo não merece o rótulo de ditadura!

Saramago estava consciente de que o discurso do poder seleciona na memória coletiva aquilo que Ihe interessa. Sob essa ótica, as comemorações em torno de Pessoa proporcionavam a renovação da "festa da raça", tão ao gosto do salazarismo, no que tange à valorização da memória dos fatos grandiosos operacionalizados pelos portugueses nos tempos passados.

$\mathrm{O}$ apego doentio a uma grandeza passada, que nada mais foi do que uma quimera e tudo aquilo que, no presente da nação, expressava o mascaramento do real rosto de Portugal: nação atrasada, de analfabetos, sem tradição científica, histórica e crítica e, mais ainda, a carregar a sina de nação periférica no certame dos povos europeus, levou Saramago a escrever esse romance de confronto de Portugal consigo mesmo.

Para isso reinventa o mais clássico dos heterônimos pessoanos, Ricardo Reis. Ao retornar a Portugal, essa figura, que age de acordo com o ideal expresso pelo verso de que "sábio é o que se contenta com o espetáculo do mundo", vai se confrontar

17 Cf. SELLIER, Philipe. Qu'est-ce qu'un mythe littéraire? Littérature. Paris, n. 55, p. 112-126, outubro de 1984.

fragmentum, n 9. Laboratório Corpus: UFSM, 2005. 
com uma realidade histórica que exige dos seres humanos mergulhados nesse turbilhão de acontecimentos algum tipo de resposta. E, como sabemos previamente, Ricardo Reis ingressa na morte sem tomar qualquer posição. Suas convicções conservadoras, católicas e clássicas são confrontadas com um dos anos mais dramáticos da história européia, o ano de 1936. Nesse período, em Portugal, consolida-se o salazarismo com o apoio das corporações financeiras e da Igreja. $\mathrm{Na}$ Itália consolida-se o fascismo com Mussolini, reavivando a vocação imperial italiana, que faz essa nação européia se jogar, qual ave de rapina, sobre a indefesa Etiópia. Na Alemanha ocorre a escalada triunfal do nazismo ao poder e a Espanha mergulha na horrenda guerra civil, que, ao opor os nacionalistas de Franco, e os socialistas vinculados ao governo legítimo, transforma o país num cenário sangrento. Esse é o ano em que o gesto ficcional de Saramago determinou como tempo derradeiro para Ricardo Reis viver e, se possível, modificar os seus reacionários valores.

$\mathrm{Na}$ melhor linha do fingimento pessoano, Saramago confronta Ricardo Reis com dois excelentes interlocutores e opositores, a criada Lídia e o seu próprio criador, Fernando Pessoa morto, o qual adquire no âmbito da morte uma visão abrangente sobre os caminhos dos vivos e os do além. Essas duas personagens irão questionar e desconstruir, ao longo dos oito meses nos quais Ricardo Reis vive, as sólidas balizas que essa figura havia estabelecido para a sua existência.

Apesar dos discursos críticos da criada Lídia e de Fernando Pessoa, das evidentes manipulações da imprensa pelo salazarismo, dos desaparecimentos misteriosos de opositores do regime, da constatação da pobreza da gente portuguesa, da triunfante ascensão dos totalitarismos, do hediondo massacre dos marinheiros em 8 de setembro, numa tentativa de derrubada da ditadura, da manipulação da religião a serviço do estado, Ricardo Reis deixa a vida sem ter efetivamente "lido" e interpretado esse tempo português. Em sua volta a Portugal, Ricardo Reis não percebe que se tratava de redescobrir a terra com aquele ônus de dor e angústia que esse processo poderia gerar. Entediada, a personagem circula por Lisboa, como espaço predileto para a sua peregrinação sem rumo e sem certeza acerca da própria identidade pessoal e do país reencontrado. Nesse sentido, Saramago impõe ao romance o mapa da Lisboa de 1936. Lisboa torna-se para a 
personagem uma cidade aberta, que possibilita um exercício de revisão da História. Assim, à imperial Lisboa Cais de Camões, à nostálgica Lisboa de Cesário, à provinciana Lisboa doceira de Eça, à Lisboa branca - monótona do filme Lisbon Story, à Lisboa bucólico-erudita do Madredeus, à Lisboa messiânica de Pessoa, capital de sua Pátria-Língua, emerge a Lisboa "Histórica" de Saramago, como espaço instaurador de um longo olhar para dentro, fundando-se numa História que sempre foi escrita com o olhar para fora a apontar Oceanos, raras vezes com o abismado olhar para o interior, que a custo suportaria o triste reflexo fulgurante de uma terra à espera da (re)descoberta.

Tais considerações enquadram o corpus escolhido como alvo da pesquisa de doutoramento e que originaria a tese: $A$ História Comanda o Espetáculo do Mundo: Ficção, História e Intertexto em O Ano da Morte de Ricardo Reis de José Saramago, defendida na UFRGS, em 2002. Ao escolher uma das obras mais significativas, complexas e menos exploradas do escritor José Saramago, O Ano da Morte de Ricardo Reis, eu pretendia situar e analisar o momento literário vivido pela Literatura Portuguesa contemporânea, investigando, ainda, a interlocução entre a Literatura e a História, bem como as relações intertextuais que a narrativa saramaguiana, em questão, estabelecia com os dois projetos literários mais expressivos da Literatura Portuguesa na busca de sua especificidade: a obra poética de Fernando Pessoa e a épica de Luís de Camões.

Com base nessa meta, investiguei, em 2000 e 2001, na Biblioteca Nacional de Lisboa, sob a orientação de Carlos Reis, $O$ Espólio de José Saramago. Na qualidade de investigador estrangeiro, que estava na Biblioteca Nacional para pesquisar sobre a produção romanesca de José Saramago, eu tive acesso a todos os fundos daquela instituição cultural relacionados com os objetivos de minha pesquisa. Dessa forma, consultei, sem qualquer impedimento, a Área de Referência, a Sala de Leitura Geral e de Periódicos e, ainda, as Salas de Reservados (fundos raros) e as Coleções Especiais.

A pesquisa nessa instituição cultural portuguesa visava aprofundar uma série de reflexões acerca da obra saramaguiana e das relações entre Literatura e História, já iniciadas no Brasil, nos dois primeiros anos de elaboração da tese. Tais reflexões empreendidas a partir de um lugar específíco, a Biblioteca Nacional 
de Lisboa, que procura preservar a memória escritural portuguesa, ganhavam evidentemente uma nova conformação e passavam a ser codificadas escrituralmente de uma forma que eu, ao iniciar o doutoramento, não poderia sequer supor.

O meu alvo principal de investigação na BN era, claro está, o Espólio de José Saramago, cujos manuscritos originais poderiam esclarecer e aprofundar o meu percurso investigativo de $O$ Ano da Morte de Ricardo Reis, centrado na interlocução entre Literatura e História como baliza condutora do estudo. Todavia, além dos manuscritos recolhidos no Espólio de Saramago, a pesquisa na Biblioteca Nacional facultava-me um aumento considerável da fortuna crítica para a redação definitiva da tese. Tal processo consistiu na coleta e leitura de artigos, ensaios e resenhas de cunho teórico-crítico sobre a obra ficcional de José Saramago. Estudos dessa natureza raramente estão disponíveis, no Brasil, considerando a escassez ou mesmo a inexistência, em nossas bibliotecas universitárias, de importantes publicações portuguesas sobre temas literários e de cultura lusitana. Como a Biblioteca Nacional de Lisboa é a depositária de todas as publicações periódicas portuguesas, a concentração de tais materiais, num mesmo lugar, facilitou a busca e a reunião desses textos. Um outro dado importante, nessa trajetória investigativa, consistiu no fato de a Biblioteca Nacional de Lisboa ser a depositária de todas as teses de mestrado e doutorado publicadas nas universidades portuguesas. Assim, tive acesso às principais reflexões acadêmicas desenvolvidas em Portugal sobre a obra saramaguiana, nos últimos 15 anos. A leitura de todos esses estudos possibilitou-me um acréscimo significativo de material bibliográfico para a tese de doutoramento, pois proporcionava-me uma visão ampla das reflexões e pesquisas que foram e que estavam sendo desenvolvidas, contemporaneamente, em Portugal e, também no Brasil, sobre o universo romanesco de José Saramago.

Considerando que uma tese de doutoramento em Letras deve ser uma reflexão original e inédita sobre um determinado âmbito de questões, eu me encontrava numa situação bastante delicada, pois a mencionada interlocução entre a Literatura e História que eu desejava empreender, mediante a análise teóricocrítica de José Saramago, já havia sido debatida e glosada à exaustão por vários investigadores, sobretudo brasileiros e lusitanos. Nesse horizonte investigativo, alguns estudiosos 
produziram excelentes estudos sobre tal enfoque interdisciplinar, condicionando, a partir de então, os estudos saramaguianos posteriores. À guisa de exemplo, refiro-me, sobretudo, ao magnífico trabalho de Teresa Cristina Cerdeira da Silva, José Saramago: Entre a História e a Ficção uma saga de portugueses (1989), estudo que assinala, no Brasil, o começo da reflexão sobre o romance saramaguiano, mas também a discussão sobre o processo de resgate e reescrita da História portuguesa pela ficção como um incontornável elemento estruturante da obra saramaguiana18. Há que destacar, ainda, o primeiro estudo publicado acerca da narrativa saramaguiana, que é O essencial sobre José Saramago (1987), de autoria de Maria Alzira Seixo, que inaugura, em termos de crítica e de teorização literárias, a reflexão sobre a produção artística saramaguiana. Esse estudo inaugural da autora e outros estudos foram posteriormente reunidos e publicados em Lugares da Ficção em José Saramago (1999), profundo estudo sobre a poesia e a prosa do autor lusitano 19 .

Eu estava, como se pode ver, "metido num sarilho". Isto é, queria escrever uma tese de doutoramento sobre Literatura e História em José Saramago, mas deveria adotar um caminho, que, mesmo valorizando uma perspectiva investigativa já encetada por outros, conduzisse à confecção de um estudo "original" sobre o romancista português. Em meio a esse processo, constatei que ainda não havia sido produzido nenhum estudo sobre a intersecção entre Literatura e História, em Saramago, a partir da investigação das fontes manuscritas do romancista, recolhidas no seu espólio da BNL. A consulta dos manuscritos originais facultava-me, assim, a possibilidade de lançar um olhar novo sobre $O$ Ano da Morte de Ricardo Reis e, também, o redimensionamento do diálogo entre Ficção e História a partir de uma perspectiva de estudo inédita, que valorizava as fontes manuscritas do espólio, cujos materiais haviam sido doados à BNL, em 1999.

O Espólio de José Saramago está depositado na Biblioteca Nacional de Lisboa com a seguinte referência: ESP.N45. Esses manuscritos são chamados também de Coleção José Saramago.

18 SILVA, Teresa Cristina Cerdeira da. José Saramago: entre a história e a ficção uma saga de portugueses. Lisboa: Dom Quixote, 1989.

19 SEIXO, Maria Alzira. Lugares da ficção em José Saramago. Lisboa: Imprensa Nacional - Casa da Moeda, 1999. 
Tal coletânea reúne vários tipos de documentos, recolhidos em caixas separadas. A saber:

Caixa 1: Cartas recebidas dos escritores Adolfo Casais Monteiro, José Rodrigues Miguéis e Massaud Moisés. E também manuscritos de terceiros como José Rodrigues Miguéis e José Gomes Ferreira.

Caixa 2: Manuscritos do Autor. Os originais de O Ano da Morte de Ricardo Reis.

Caixa 3: Documentos biográficos. Diploma do Nobel.

Caixa 4: Manuscritos de terceiros/de Aleixo Ribeiro, José Rodrigues Miguéis e um manuscrito do autor "O Embargo".

Caixa 5: Correspondência - Cartas recebidas e algumas enviadas.

A consulta ao espólio do autor revelou-se extremamente valiosa, pois nos concentramos no exame da Caixa 2, na qual estão recolhidos os manuscritos originais do romance e uma série de anotações feitas pelo autor, antes de se lançar ao processo de escrita dessa obra. A Caixa 2 apresenta os seguintes documentos:

1) Texto fotocopiado do romance $A$ Conspiração de Tomé de Sousa;

2) Manuscritos do Autor: Os originais de $O$ ano da Morte de Ricardo Reis. Trata-se do texto datilografado com correções ortográficas do romance (465 páginas).

3) Uma Agenda azul do ano de 1983. A agenda consiste de um conjunto de anotações do autor. As datas relativas a 1983 foram alteradas por Saramago e substituídas por outras que cobrem o período de dezembro de 1935 a 8 de setembro de 1936. As notas feitas pelo romancista apontam para os registros cotidianos de hábitos lisboetas, temperaturas do dia, acontecimentos políticos referentes a Portugal, 
Espanha, Alemanha e Itália. Nessa agenda, estão as fichas de solicitação de material, utilizadas pelo romancista, indicando que a pesquisa prévia para elaboração do romance se estendeu de maio a julho de 1983.

4) Páginas datilografadas de apontamentos preparatórios para o romance (cerca de oito páginas). A primeira página é um esboço de biografia previsto por Pessoa para Ricardo Reis e que faz alusão à carta de 13 de janeiro de 1935 a Adolfo Casais Monteiro. A segunda página é um esboço de "releitura absurda" das odes de Ricardo Reis, as quais poderiam ser reinventadas pelo romance. As páginas seguintes são considerações datilografadas sobre a pesquisa documental realizada para a escrita do romance. Essas anotações são interessantíssimas, pois ao serem cotejadas com 0 romance, permitem a verificação do caminho escritural que levou à narrativa acabada.

5) Material fotocopiado do Diário de Lisboa, de dezembro de 1972, sobre a notícia da morte de Pessoa na imprensa do tempo.

6) Cópia de um livro de Modesto Carrone sobre a Esquerda Brasileira. A utilização desse texto se explica, pois os acontecimentos de 30 no Brasil, como a marcha de Prestes e a Revolução de 30, são responsáveis pela volta de Ricardo Reis a Portugal.

Depois do exame desse material heterogêneo, orientei o esforço para a decifração das informações contidas na "Agenda Azul". Essas informações obtidas da agenda remetiam para dados, figuras e acontecimentos históricos presentes no romance, cuja representação na narrativa de José Saramago constituía o alvo da minha investigação de doutoramento.

$\mathrm{Na}$ agenda, aparecem enumeradas, em ordem cronológica, notícias históricas do ano de 1936, em Portugal e no resto da Europa, as quais foram utilizadas pelo romancista para a realização de uma coerente e harmônica ambientação histórica do universo romanesco. As anotações da Agenda se estendem do dia $1^{\circ}$ de Janeiro ao dia 8 de setembro de 1936. Elas foram feitas pelo autor 
com base na leitura do jornal lisboeta $O$ Século, o de maior circulação nas três primeiras décadas do século XX.

Depois de dissecada a Agenda, confrontei as anotações e dados veiculados por ela com os acontecimentos históricos retratados pelo jornal $O$ Século, disponível em micro-filme. Ao realizar isso, constatei que as informações históricas presentes no romance de José Saramago expressavam uma correspondência, às vezes literal, com as notícias encontradas no jornal O Século. Os dados obtidos, através da investigação do espólio de José Saramago foram utilizados na elaboração da tese de doutoramento, na qual procurei confrontar e analisar o diálogo dos fragmentos jornalísticos do Jornal O Século com o romance O Ano da Morte de Ricardo Reis.

De todos os romances saramaguianos, $\mathbf{O}$ Ano da Morte de Ricardo Reis é, talvez, o mais denso em informações históricas, no que concerne à matéria basilar para a codificação romanesca. Acreditamos que isso está longe de ser um defeito, pois a abundância de dados históricos circulantes pelo universo narrativo está a serviço de uma perfeita conformação da atitude da personagem Ricardo Reis, diante da precipitação dos acontecimentos desse tempo. Essa coerência entre a revisitação de 1936 e a constituição moral de Ricardo Reis é destacada pelo próprio romancista, o qual afirma que há uma sobrecarga evidente de informação na obra, porque a intenção era quase asfixiar o leitor sob aquela massa de notícias que, por sua vez, estão a sufocar o Ricardo Reis 20 .

Com base nesse enfoque, o processo de reescrita da História promovido pela ficção fundamenta-se na apropriação, diluição e na problematização crítica pela estrutura romanesca das notícias de jornal referentes ao contexto histórico-social lusoeuropeu, que a personagem Ricardo Reis apreende, sobretudo, pela leitura das páginas de O Século, periódico de maior circulação na Lisboa daqueles anos cinzentos. A presença do artefato jornalístico é fundamental para a criação do universo ficcional saramaguiano no romance em questão, pois configura-se como um dos recursos deflagradores da intertextualidade na narrativa. A utilização de

20 SARAMAGO, José apud VASCONCELOS, José Carlos de. José Saramago: Gosto do que este país fez de mim. JL-Jornal de Letras, Artes e Idéias, Lisboa, n.354, p. 8-10, 18 a 24 de abril de 1989. 
fragmentos oriundos da imprensa escrita caracteriza uma elaboração artística baseada num contraponto. Isto é, o jornal cria uma conformação histórica aceitável, no que tange à representação da época focalizada pelo romance. A partir desse enfoque, o exame dos manuscritos do autor para a gênese de $\mathbf{O}$ Ano da Morte de Ricardo Reis revela, como elemento perceptível na estruturação do texto acabado, um atento e minucioso folhear dos textos jornalísticos de 1936, particularmente, do jornal O Século.

O jornal forneceu ao escritor uma série de dados factuais sobre o ano de 1936, proporcionando uma verdadeira encenação dos costumes de um mundo que já não pertence mais à experiência da maior parte dos leitores do romance. Assim, tomamos contato, não só com dados relativos à situação política luso-européia, mas também com casos pitorescos do tempo, como os crimes da Mouraria e o caso Luis Uceda, as peripécias do intrépido Seiscentos Maluco, as peças teatrais e filmes em cartaz, além de uma gama variada de anúncios sobre produtos, reveladores dos gostos e dos hábitos de consumo desse período, emblematicamente representados pelos anúncios das oficinas de Freire Gravador, que Ricardo Reis percorre com curiosidade. O manuseio dos jornais para a confecção da trama narrativa produz um exitoso efeito de reconstituição histórica que Óscar Lopes definiu nos seguintes termos:

O caso de O Ano da Morte de Ricardo Reis é particularmente interessante porque nenhum outro romance de Saramago mobiliza um tão minucioso conjunto de dados históricos, simultaneamente registrados em jornais e numa experiência testemunhal mais ou menos comum a quem (como também, por sinal, o responsável destas linhas) tenha vivido o ano crucial de 1936 em Lisboa; o motivo de mais espontâneo interesse por este romance é de facto, esse, a que já nos referimos, da evocação de uma dada época, a de há cerca de meio século, numa amostragem flagrante colhida a longo dos primeiros meses de 1936. Pelo enlace dos dados 
factuais e de pormenores que reconstituem todo o ambiente histórico de Lisboa, $[. . .]^{21}$.

O romance não se limita, porém, a essa "amostragem flagrante" que consistiria em diluir na malha discursiva a referência jornalística, mas vai além, promovendo a elevação de outras vozes, muitas vezes dissonantes em relação ao enunciado dos jornais e em relação à leitura que a personagem Ricardo Reis realiza das páginas noticiosas. São as vozes das outras personagens romanescas acompanhadas da entonação irônica, zombeteira, crítica e desconstrutora do narrador. É uma voz veemente ao manifestar a possibilidade de rejeitar a enunciação jornalística tendenciosa, elaborada por uma imprensa pactuante com o poder ditatorial.

Com base no exposto, as notas jornalísticas constituem-se em fontes imprescindíveis para a obtenção de uma reconstituição e ambientação histórica plausível. Além de informarem a Ricardo Reis, os jornais permitem a essa figura, ficção de uma ficção pessoana, obter dessas páginas a confirmação de uma verdade paradoxal: a morte de seu criador Fernando Pessoa e, sobretudo, a indefinição acerca da sua existência como figura remanescente e autônoma em relação ao trânsito pessoano. Mesmo sabendo que tudo é fingimento, na melhor linha pessoana, os fatos fundamentais no tratamento da História são dados pela leitura dos jornais como transcrições a que o narrador ou as personagens acrescentam comentários. Assim, a realidade e a ficção mesclam-se para compor a moldura do retrato de Ricardo Reis.

O Ano da Morte de Ricardo Reis é um dos melhores testemunhos da criatividade do novíssimo romance português, surgido após a Revolução dos Cravos de 1974. Nesse sentido, essa obra saramaguiana sintomatiza tendências marcantes da ficção portuguesa contemporânea, tais como o pendor crítico, a combatividade, a auto-reflexividade discursiva e a predileção pelo resgate e transfiguração da História portuguesa em Ficção. Ao ser submetida ao crivo da ironia e do questionamento, a História lusitana é reescrita como âmbito assinalado por uma pluralidade de caminhos que não originam uma única História possível.

21 LOPES, Óscar. José Saramago: as fronteiras do maravilhoso real. In: Os sinais e os sentidos. Lisboa: Caminho, 1988, p. 210-211. 


\section{SOBRE O AUTOR}

Gerson Luiz Roani é licenciado em Letras pela Universidade Federal de Santa Maria. Obteve o grau de Mestre em Literatura Comparada pela Universidade Federal do Rio Grande Sul. Nessa mesma universidade doutorou-se em Literatura Comparada, em 2002, com uma tese sobre José Saramago. Em 2000 e 2001, foi bolsista da CAPES na Biblioteca Nacional de Lisboa, investigando o Espólio de José Saramago. Leciona Literatura Portuguesa e Teoria da Literatura na Graduação e Pós-Graduação da Universidade Regional Integrada do Alto Uruguai e das Missões - URI. Desenvolve e orienta projetos de pesquisas relacionados às áreas da Literatura Portuguesa e da Literatura Comparada. No CNPq, coordena o grupo: Romance Português e História: A Ficção de José Saramago. É autor dos livros: Intertextos no Barroco Brasileiro (Ed.URI), No limiar do texto: literatura e História em José Saramago (Annablume) e Literatura e judaísmo: o rosto judeu de Borges (Ed. da UFRGS). 